\title{
Runoff and soil loss in undisturbed and roller-seeded shrublands of semiarid Argentina
}

\author{
MANUEL O. AGUILERA, DIEGO F. STEINAKER, AND MANUEL R. DEMARIA
}

Authors are Range Scientist, Biologist, and Wildlife Ecologist, San Luis Experimental Station, Instituto Nacional de Tecnología Agropecuaria (INTA), CC 17, Villa Mercedes, 5730, San Luis, Argentina.

\begin{abstract}
Vegetation influences runoff and soil losses in semiarid environments. In shrublands of Central Argentina, grazing has resulted in a reduction of plant cover, an increase in the proportion of bare soil, and eroded soils. Patterns of runoff and soil losses affected by seeding cultivated grasses were evaluated. We investigated the effects of roller-seeding of Cenchrus ciliaris $L$ and the influence of microsite cover-type on the dynamics of water erosion. Evaluated cover-types were: bare soil, shortgrass cover, and tallgrass cover. Evaluations were performed 2 growing seasons after roller-seeding. The experimental design was a split-plot, replicated 3 times using a portable rainfall simulator. After simulation runs of $45 \mathrm{~min}$ at an average rate of $110 \mathrm{~mm}$ hour ${ }^{-1}$, runoff of tallgrass cover was the least, whereas bare soil and shortgrass cover had similar values (ca. 60\%). However, both types of grass cover reduced soil splash compared to the bare soil cover-type. An exponential function between runoff and soil loss suggested that increasing runoff beyond $60 \%$ produced an abrupt rising of sediment loss. Roller-seeding did not influence runoff or sediment loss at the microsite-scale. Nevertheless, roller-seeding reduced the proportion of area covered by microsites prone to erosion (bare soil and shortgrass cover-types) at the whole plot level. We propose that any management tool that promotes the replacement of bare soil and shortgrasses by tallgrasses should reduce runoff and increase forage productivity via amelioration of hydrologic conditions of the rangeland site. Conversely, overgrazing will result in more bare soil, increasing runoff, and further intensifying the loss of sediments by detachment.
\end{abstract}

Key Words: rainfall simulator, runoff, semiarid shrublands, soil erosion, vegetation cover

\footnotetext{
Research was funded by the National Institute of Agricultural Technology of Argentina (INTA). Authors thank Andrew Mack and Eleni A. Kalitsis, scholars of the Association of Canadian Community Colleges (ACCC), for their help in data collection. Other important contributors to this study were: A. Belgrano Rawson who permitted this study at Estancia Lomas Blancas, S. Sayavedra who carried out the construction of the rainfall simulator, and N. Maceira who promoted the intership program in San Luis. The manuscript was improved by comments from $\mathrm{C}$. Mario Rostagno, David L. Anderson, Carlos B. Passera, and two anonymous reviewers.

Manuscript accepted 25 Aug. 02
}

\begin{abstract}
Resumen
La vegetación afecta los patrones de escorrentía y pérdida de suelo en los ambientes semiáridos. En arbustales del Centro de Argentina, el pastoreo ha producido reducciones en la cobertura vegetal, aumento del suelo desnudo, y erosión. Se evaluaron los patrones de escorrentía y pérdida de suelo afectados por tratamientos de siembra de pastos cultivados mediante el rolado. Nuestro estudio examinó los efectos del rolado y siembra de Cenchus ciliaris $\mathrm{L}$ y la influencia del tipo de micrositio en la dinámica de la erosión hídrica. Los tipos de cobertura evaluados fueron: suelo desnudo, cobertura de pastos cortos, y cobertura de pastos altos. Las evaluaciones se realizaron 2 estaciones de crecimiento después del tratamiento de rolado y siembra. El diseño experimental fue de parcelas divididas, replicado 3 veces utilizando un micro simulador de lluvia móvil. Después de simulaciones de $45 \mathrm{~min}$ a una tasa promedio de $110 \mathrm{~mm} \mathrm{~h}^{-1}$, la escorrentía en pastos altos fue la menor, mientras que en suelo desnudo y en pastos cortos fue similar (aprox. 60\%). Sin embargo, ambos tipos de cobertura de pastos redujeron el desprendimiento de sedimentos comparando con el caso de suelo desnudo. La relación entre escorrentía y pérdida de suelo fue exponencial. La pérdida de sedimentos aumentó abruptamente cuando la escorrentía superaba $60 \%$. El tratamiento de rolado y siembra no afectó la escorrentía ni la pérdida de sedimentos a la escala de micrositio. De todas maneras, el rolado redujo la proporción de micrositios más sensibles a ser afectados por erosión (suelo desnudo y cobertura de pastos cortos). Nosotros proponemos que cualquier herramienta de manejo que promueva el reemplazo de suelo desnudo y de pastos cortos por pastos altos debe reducir la escorrentía e incrementar la productividad forrajera mediante el mejoramiento de las condiciones hidrológicas del sitio. A la inversa, una mayor degradación con mayor proporción de suelo desnudo llevará los valores de escorrentía a más del $60 \%$, desencadenando el proceso de desprendimiento de sedimentos.
\end{abstract}

In semiarid and arid regions vegetation causes spatial heterogeneity at the microsite level, changing the pattern of water flux, therefore affecting runoff and soil losses (Weixelman et al. 1997, Cammeraat and Imeson 1999, Cerdá 1999, Reid et al. 1999, Valentin et al. 1999). Grazing can affect the pattern of vegetation cover, resulting in greater soil erosion (Wood and Blackburn 1981, 1984, Braunack and Walker 1985, Naeth et al. 1990, Chanasyk and Naeth 1995). The effects of grazing include: reduction of plant biomass, compaction of soil, reduction of litter, and undesiderable successional trends. These unfavorable trends 
often result in the replacement of bunchgrasses by sodgrasses affecting water infiltration responses (Knight et al. 1984, McCalla et al. 1984, Eckert et al. 1986, Blackburn et al. 1992).

In Central Argentina (provinces of San Luis, Córdoba and La Rioja), livestock grazing is widespread resulting in undesirable vegetation changes and soil erosion (Báez 1946, Morello 1958, Cabido et al. 1994). Adjusting livestock rates and allowing rest to grazed paddocks have resulted in positive changes of range condition (Anderson et al. 1980). Improvement of range condition is associated with the replacement of colonist shortgrasses for more productive tallgrasses (Anderson et al. 1980). Additionally, the incorporation of Cenchrus ciliaris L (Buffel grass) is primarily a management strategy to provide rapid, initial establishment of a grass cover on denuded areas. Buffel grass is recommended because it is a perennial species that establishes rapidly, produces palatable forage, and is tolerant to drought (Namur 1985, Skousen and Call 1987). However, Buffel grass has a high percent failure for colonization due to lack of runners and poor competitive ability of seedlings (Gardener and McIvor 1986, Hacker 1989). Buffel grass would also be effective in areas where there is a lack of vegetation recovery because of reduced local seed sources and seed banks (Basher and Lynn 1996). The most common equipment used to incorporate Buffel grass is a roller-chopper with the addition of a seeding device.

Some studies have been conducted in Argentina simulating roller disturbance to determine the percent recovery of shrubs and grasses (Passera et al. 1992, 1996). However, the effects of the roller equipment on runoff, soil loss, and Buffel grass establishment have not been studied. Passera et al. (1992) found that after shrub removal, litter cover was $60 \%$ greater and establishment of native grasses was augmented in treated areas. A later study on the effects of shrub control showed that reduction without elimination of woody plants and site disturbance allowed the reappearance of early successional species, native forbs and grasses (Passera et al. 1996). However, in areas with high grass cover, shrub removal did not result in significant increases of forage species (Passera et al. 1996). This suggested that shrub removal would only be advisable in denuded pastures and overgrazed areas.

No studies have been conducted to determine the effects of revegetating Buffel grass using the roller technique on

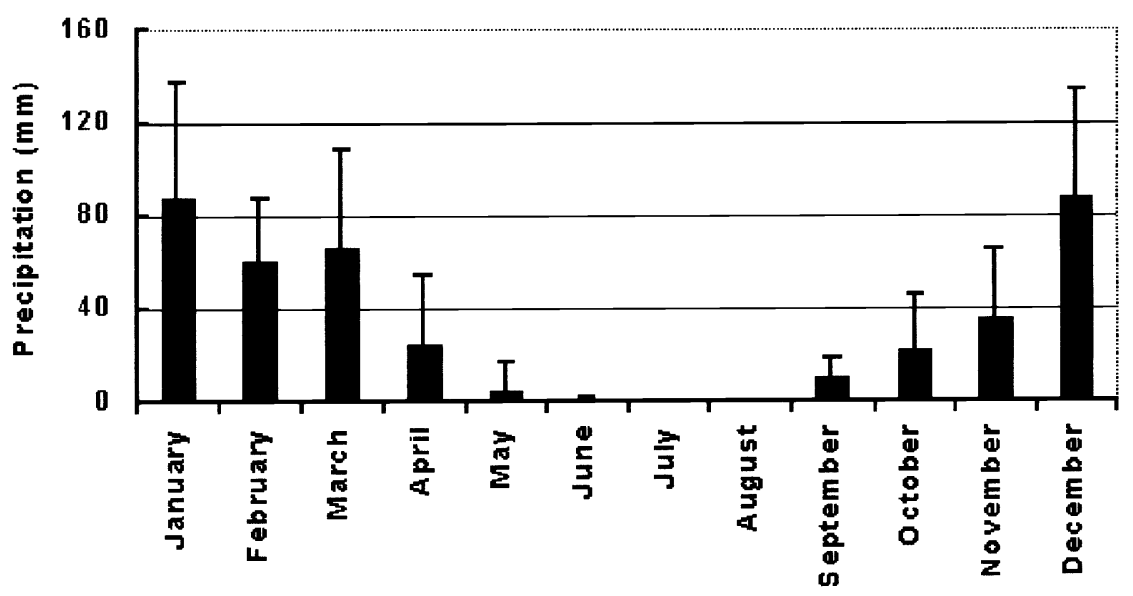

Fig. 1. Monthly average precipitation $(X \pm S D)$ at Ea. Lomas Blancas, San Luis (1990-1999). Annual average precipitation $=399.9 \pm 75$.

the reduction of soil erosion. The objective of this experiment was to provide further knowledge on the hydrological consequences of roller-seeding eroded shrubland sites. In addition, we estimated soil erosion and runoff for different types of microsites. Evaluated microsites were: a) soil denuded of vegetation, b) areas covered with shortgrasses, and c) areas covered with tallgrasses. In Central Argentina, degraded rangelands usually have a high proportion of bare soil and shortgrass microsites. After revegetation, these microsites are colonized by vigorous tallgrasses. Runoff and soil losses were evaluated in roller-seeded plots, and in undisturbed controls using a portable rainfall simulator.

\section{Study site}

The study site is located in northern San Luis Province, Argentina, in the ecotone between the Monte to the west and the arid Chaco to the northeast (Morello 1958). The ecotone is an open woodland with an uneven cover of trees and a mostly continuous herbaceous layer (Mares et al. 1985). Dominant genera of woody plants are: Acacia, Aspidosperma, Geoffroea, Larrea, and Prosopis (Anderson et al. 1970, Cabrera 1971, Peña Zubiate et al.
1998). Perennial grasses dominate the herbaceous layer in areas with mean annual precipitation $>300 \mathrm{~mm}$ (Cabido et al. 1993). Aristida, Chloris, Digitaria, Eragrostis, Neobouteloua, Pappophorum, Setaria, and Trichloris are typical warmseason-grass genera (Anderson et al. 1970, Peña Zubiate et al. 1998).

The study was conducted at Estancia Lomas Blancas (3243'54"S 66 $\left.44^{\circ} 32^{\prime \prime} \mathrm{W}\right)$. The ranch is approximately $80 \mathrm{~km}$ northwest of the city of San Luis. The elevation is $600 \mathrm{~m}$ asl and the region receives on the average $400 \mathrm{~mm}$ of rain per year, with the majority falling in the summer (Fig. 1). Storms are frequently torrential, lasting short periods but with high intensity. These events may be responsible for sharp changes in the dynamics of water erosion which so dramatically affect soil loss. Unfortunately, data on precipitation intensity is lacking for the site. Our study focussed on the dynamics of erosion in response to rainfall events of high intensity.

The soil at the study site is a Typic Haplocalcid (Peña Zubiate, personal communication), with signs of sheet erosion (Table 1). Typic Haplocalcids are common in desert areas of the world (Soil Survey Staff 1999). At Lomas Blancas, the subsoil is often at the surface. The overall slope is $1 \%$. The microtopography is undulating with some evidence of erosion.

Table 1. Soil characteristics before the experiment. Horizon depth, organic matter, total N, texture and $\mathrm{CaCO}_{3}$ of the study area: Typic Haplocalcid, Lomas Blancas series (Peña Zubiate C., personal communication).

\begin{tabular}{ccccccc}
\hline \hline Depth & Organic matter & Total N & Sand & Silt & Clay & $\mathrm{CaCO}_{3}$ \\
\hline$(\mathrm{cm})$ & $(\%)$ & $(\%)$ & $(\%)$ & $(\%)$ & $(\%)$ & $(\%)$ \\
$0-15$ & 1.5 & 0.08 & 66.4 & 30.6 & 3.0 & -- \\
$15-35$ & 1.1 & 0.06 & 69.8 & 27.7 & 2.5 & -- \\
$35-70$ & 0.9 & 0.06 & 55.3 & 35.5 & 9.2 & 10 \\
$>70$ & 0.6 & 0.04 & 50.1 & 45.2 & 4.7 & 15 \\
\hline
\end{tabular}




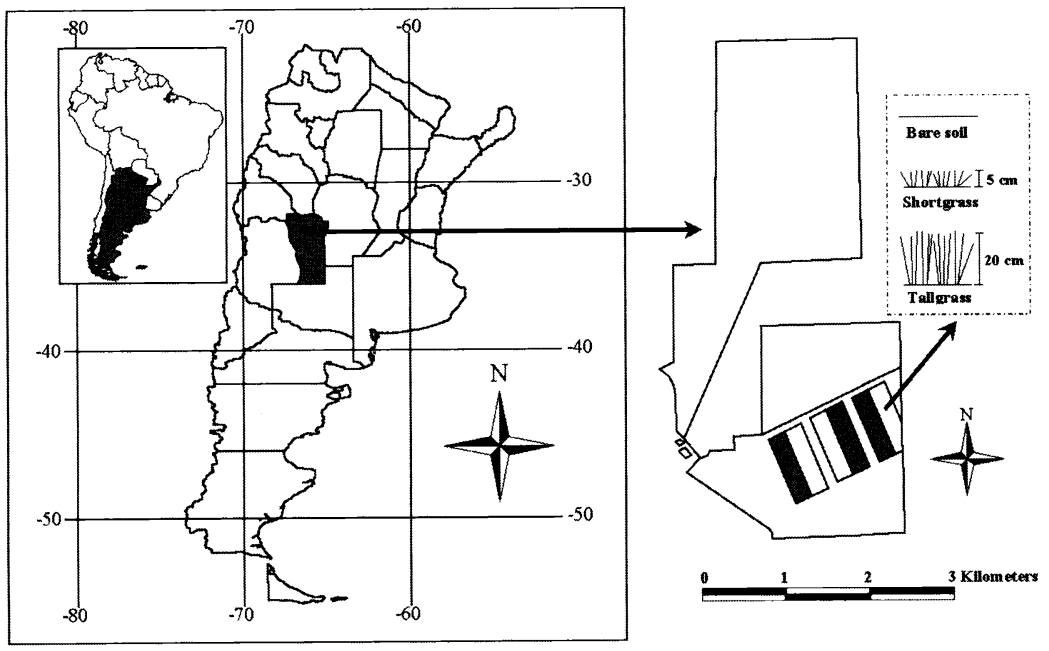

Fig. 2. Location of San Luis Province in Argentina, paddocks at Lomas Blancas Ranch, and experimental plots $($ white areas $=$ controls, shaded areas $=$ roller-seeded). Microsite covertypes were considered sub-plots according to a split-plot design.

Most ranches in the area utilize these woodland sites as grazinglands for livestock (cows and goats). In areas not protected from grazing, vegetation is patchily distributed with areas of bare soil as large as $100 \mathrm{~m}^{2}$ in the intershrub spaces. The most conspicuous tree is Prosopis flexuosa (Lag.) DC, algarrobo. The shrub Larrea divaricata Cav, jarilla, is the dominant species. Sites physognomy is characterized as jarillales, creosote scrub, (Morello 1958, Cabido et al. 1994).

\section{Materials and Methods}

The experimental area was divided into 4 blocks. Blocking was applied across a gradient in the abundance of creosote bush (Fig. 2). One half of each block was randomly selected and treated with a tractor driven roller-chopper on 15 January 1998. Controls and rolled-seeded areas were of 2-4 ha each. The roller weighs approximately $6000 \mathrm{~kg}$. Buffel grass seed was simultaneously incorporated into the soil at a rate of $5 \mathrm{~kg} \mathrm{ha}^{-1}$. Adult Prosopis-trees were left intact. On the other hand, shrubs were cut and chopped into pieces. Seedling emergence was satisfactory; not only for Buffel grass, but also for native grasses, resulting in a mixture of introduced and native species growing in the treated area. However, seedling mortality reduced Buffel grass density, as it is usually observed in these types of seedings (M.O. Aguilera, personnal observation). At the time of erosion evaluation, cover was estimated (Table 2) using the point quadrat method (Daget and Poissonet 1971) modified for the Monte region by Passera et al. (1983).
Runoff and soil losses were estimated in seeding. For this study, only 3 of the 4 blocks were sampled $(n=3)$. Time constraints in data collection and change in environmental conditions caused this reduction in replicates. Within treated and control areas, microsites that accounted for a determined set of characteristics were selected in the following manner. Three types of microsites were evaluated (Fig. 2) for each block and treatment combination $(\mathrm{N}=18 ; 3$ blocks $\times 2$ treatments x 3 microsite-types): (a) bare soil, (b) shortgrass cover (Neobouteloua July 1999, about 18 months after roller-

${ }^{1}$ Nomenclature follows Anderson et al. (1970). loposthachya [Gris.] Gould), and (c) tallgrass cover (Aristida mendocina Phil). Both species were the most abundant grasses in undisturbed and treated areas (Table 2). A point was randomly located $10 \mathrm{~m}$ beyond the boundaries of control and treated areas to avoid edge effects. Microsite types, nearest to the selected point, were chosen for locations to be evaluated using a portable rainfall simulator. Erosion plots were located away from influence of woody-species cover by determining a minimum distance of $2 \mathrm{~m}$ from the plot to the edge of surrounding canopies. In addition, 2 erosion plots under the influence of Prosopis-trees were evaluated. These were not included in the analysis of variance because of a lack of adequate replication, besides the unrealistic situation of responses to simulated rainfall under the tree canopy. However, these estimates provided valid responses for a non-eroded condition and were included in the correlation analyses $(\mathrm{N}=$ $18+2=20$ ).

In determining plot locations, flat areas with no slope were selected. Accounting for slope was a critical factor because of the small dimensions of the erosion plot $\left(625 \mathrm{~cm}^{2}\right)$ so that microsite-type and treatment were the only influencing factors. More than $90 \%$ of the plot corresponded to the cover-type evaluated. Plots were always located in areas with similar topography, at the top of the catena. Circular areas of bare soil microsites with at least a $1 \mathrm{~m}$ radius were selected to avoid the

Table 2. Relative cover (\%) of undisturbed and roller-seeded shrublands, after 18 months of imposing treatments, in Ea. Lomas Blancas, San Luis, Argentina (Steinaker D.F., personnal communication). Note: $0.0 \%$ cover indicates cover values less than $0.1 \%$.

\begin{tabular}{|c|c|c|c|}
\hline Cover-type & Species $^{1}$ & Undisturbed & Roller-seeded \\
\hline & & $(\%)$ & $(\%)$ \\
\hline Bare-soil & & 35.4 & 17.8 \\
\hline Litter & & 2.0 & 18.3 \\
\hline \multirow[t]{3}{*}{ Shrubs-Trees } & Larrea divaricata $\mathrm{Cav}$ & & \\
\hline & Prosopis flexuosa (Lag.) DC & 10.6 & 5.4 \\
\hline & & 0.0 & 0.0 \\
\hline \multirow[t]{4}{*}{ Shortgrasses } & Neobouteloua lophostachya (Gris.) Gould & 19.2 & 6.2 \\
\hline & Sporobolus pyramidatus (Lam.) Hitchcook & 3.0 & 0.0 \\
\hline & Eragrostis orthoclada Hackel & 2.5 & 1.7 \\
\hline & Aristida adscencionis $\mathrm{L}$ & 2.0 & 2.1 \\
\hline \multirow[t]{7}{*}{ Tallgrasses } & Aristida mendocina Phil & 17.2 & 28.2 \\
\hline & Pappophorum caespitosum R.E.Fr. & 3.0 & 2.1 \\
\hline & Pappophorum philliphianum Parodi & 1.0 & 0.0 \\
\hline & Gounia paraguariensis (O.K.) Par & 1.0 & 1.7 \\
\hline & Digitaria californica (Benth.) Henrard & 0.5 & 1.2 \\
\hline & Setaria leucopila (Lam-Scrib.) K. Schuman & 0.0 & 0.4 \\
\hline & Cenchrus ciliaris $\mathrm{L}$ & 0.0 & 3.7 \\
\hline \multirow[t]{2}{*}{ Forbs } & Conyza sp. & 2.0 & 10.0 \\
\hline & Other herbs & 0.5 & 1.2 \\
\hline
\end{tabular}


interference of the surrounding vegetation. Four bulk density samples (0-5 cm depth) were taken, one in each corner, outside the erosion plot. Bulk density was analyzed using the core method (Black 1965). Statistical analyses were performed for plot means $(n=3)$, and no differences were found between microsites or treatments. The overall mean of bulk density suggested that superficial soil was compacted in all microsites $\left(1.59 \mathrm{~g} \mathrm{~cm}^{-3}\right)$. Samples collected under the influence of Prosopis-trees with higher organic matter, showed significantly lower bulk density values $\left(1.36 \mathrm{~g} \mathrm{~cm}^{-3}\right)$. Most of the cover of each treatment was represented by the tested microsites (Table 2).

Rainfall was applied with a portable drop-forming rainfall simulator. This is a $150-\mathrm{cm}$ high mobile simulator built of acrylic with a square base (internal side = $25 \mathrm{~cm}$ ) driven into the soil (Irurtia and Mon 1994). The rainfall chamber has 49 tubing tips of $0.5 \mathrm{~mm}$ inside diameter. According to Irurtia and Mon (1994) generated raindrops are $5.1 \mathrm{~mm}$ in diameter and achieve a final velocity of $5.09 \mathrm{~m} \mathrm{sec}^{-1}$, delivering a kinetic energy of $15 \mathrm{~J} \mathrm{~m}^{-2} \mathrm{~mm}^{-1}$. Sufficient rainfall was applied to ensure runoff from all microsites at a nominal rate of $110 \mathrm{~mm}_{\text {hour }}{ }^{-1}$.

Runoff was collected at 5-min intervals during 45-min simulated rainfall events. Runoff (\%) was defined as the ratio between the runoff and the simulated rainfall volumes for a given period. The soil was dry previous to the simulations. Depth of the wetting front was measured by excavating in the soil after each simulated rainfall. Estimates per plot were the average of three measurements that were recorded over the plot area using a measurement tape. Soil loss was estimated from the total runoff collected by filtering through a \# 1 Whatman filter, drying at $105^{\circ} \mathrm{C}$ for 24 hours, weighting and converting the obtained sediment to soil detachment in $\mathrm{g} \mathrm{m}^{-2}$.

A split-plot design (Fig. 2) was used to determine the significance of blocks (3), whole plots $=$ treatment (undisturbed or roller-seeded areas), subplots = micrositetype (bare soil, shortgrass cover, or tallgrass cover), and the interaction term (treatment $x$ microsite). Runoff $(\%)$ was arc-sine transformed to satisfy assumptions of normality and homoscedasticity. Arc-sine transformation is often recommended for rates (Snedecor and Cochran 1980). For similar purposes, logarithmic transformation was applied to soil loss ( $\mathrm{g}$ $\mathrm{m}^{-2}$ ). Repeated-measure analysis of the transformed variables was considered at 5 ,
$10,15,20,25,30,35,40$, and $45 \mathrm{~min}$ of the elapsed time of the simulated rainfall event. Actual application rate was $109.7 \pm$ $8.29 \mathrm{~mm}$ hour $^{-1}$ (mean $\pm \mathrm{SD}, \mathrm{CV}=7.5 \%$ ), so runoff rates were adjusted by the water application rate for each recorded time (Frasier et al. 1998). Final accumulated runoff $(\%)$ and soil loss $\left(\mathrm{g} \mathrm{m}^{-2}\right)$ were analyzed separately as steady-state erosion parameters. Steady-state condition was defined at $45 \mathrm{~min}$ because no significant time-based differences were observed after $40 \mathrm{~min}$. Analyses of variance were based on restricted likelihood estimation and Satterthwaite's procedure for approximating F-tests, particularly suited for split-plot analysis (Schabenberger, O. 1996. "Some tricks about analyzing split-plot designs", http://www.stat.vt.edu/ oliver/SplitPlot.html).
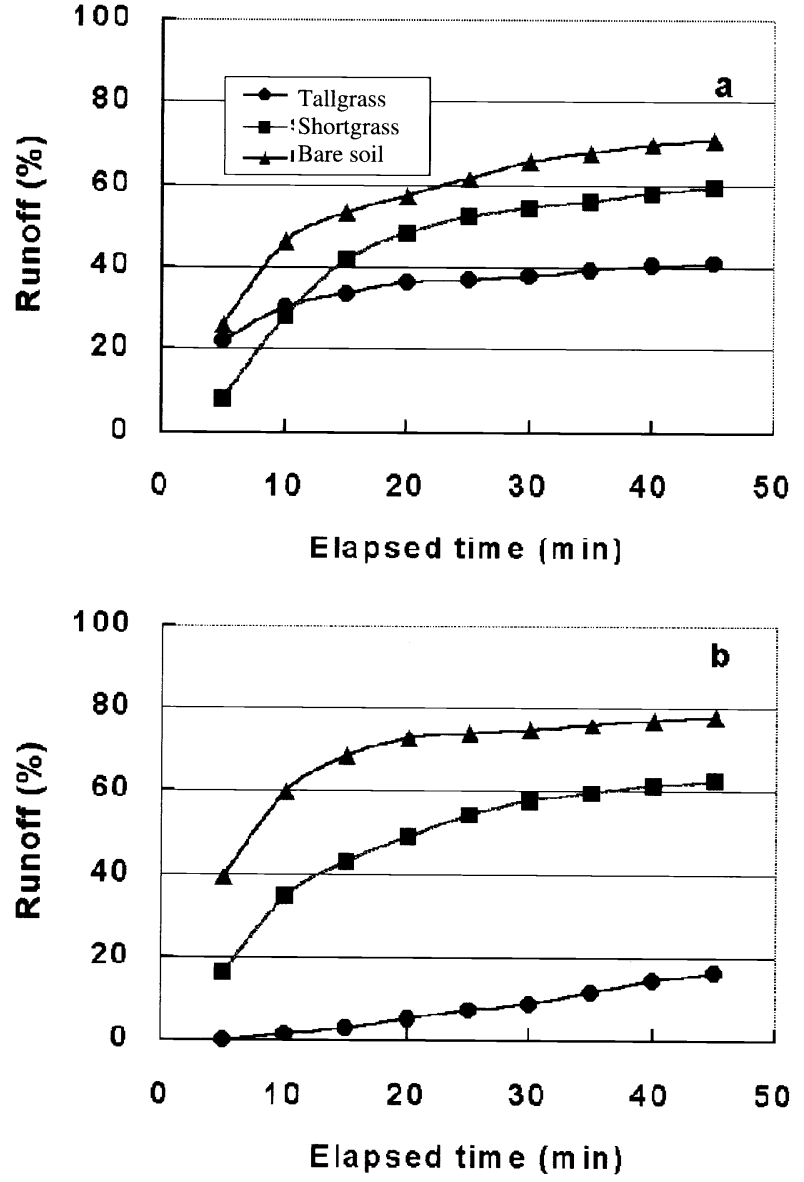

Fig. 3. Runoff (\%) under undisturbed (a) and roller-seeded (b) sites in semiarid shrublands of Argentina. Runoff simulation runs lasted $45 \mathrm{~min}$ at a nominal average rain intensity of $110 \mathrm{~mm}$ hour $^{-1}$. The only significant time- $x$ factor- interactions was time $x$ microsite because differences increased over time $(P<0.0001)$. 

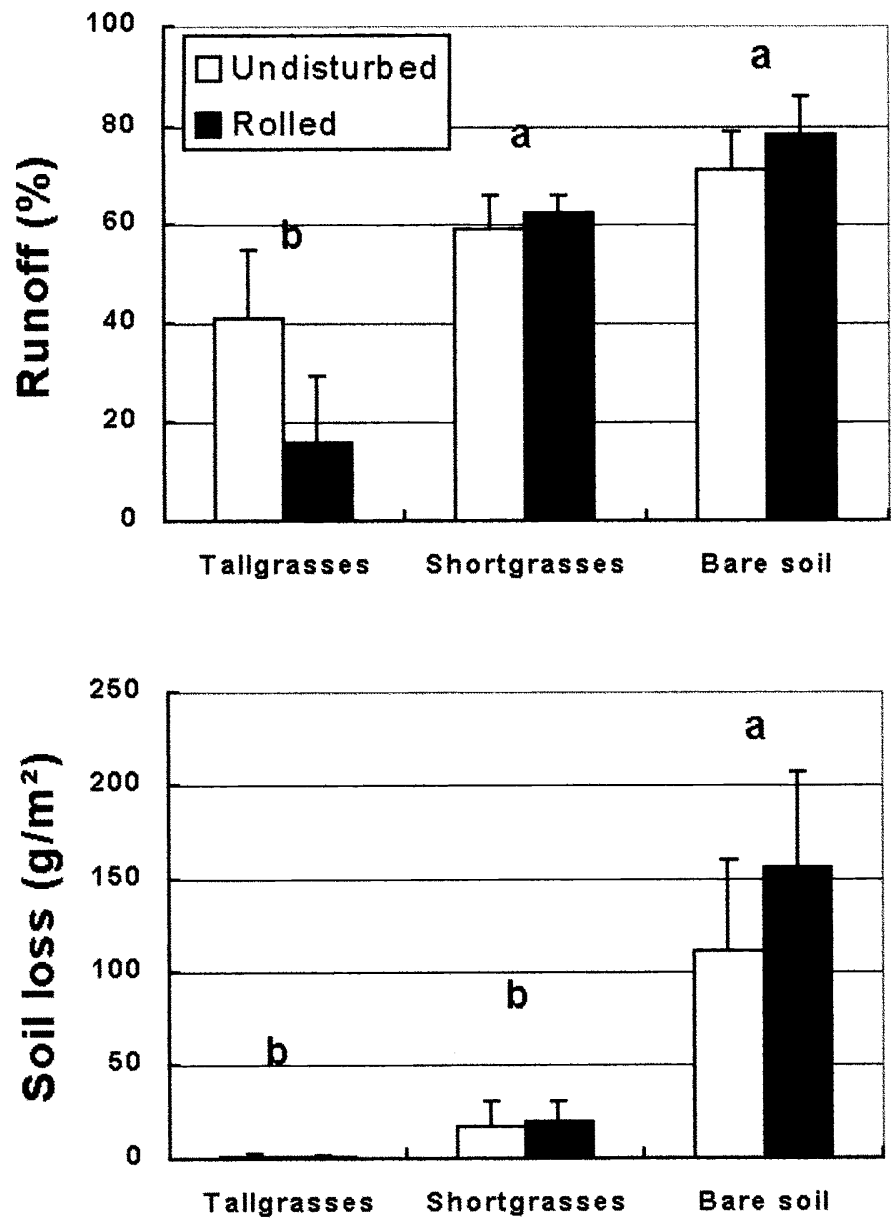

Fig. 4. Effect of treatment (undisturbed or roller-seeded) and microsite (tallgrass, shortgrass and bare soil cover-types) on runoff and soil loss after simulation runs of $45 \mathrm{~min}$ at an average rain intensity of $110 \mathrm{~mm}$ hour $^{-1}$. Different letters indicate significant differences between cover-types at $5 \%$ level. Treatment and treatmeant $x$ microsite interaction was not significant. Vertical lines on top of bars are SD.
Digitaria californica [Benth.] Henrard, Diplachne dubia [H.B.K.] Scribn., and Setaria leucopila [Lam-Scrib.] K.Schuman). If tallgrasses are already abundant in the site, little is attained by roller-seeding in terms of forage production (Passera et al. 1996).

Roller-seeding changed the proportion of microsite-cover types (Table 2) reducing bare soil and shortgrasses of scant biomass, and increasing tallgrasses. Rolling did not affect infiltration patterns at the microsite-scale, but may reduce runoff at larger scales. Runoff (\%) was closely related to depth of the wetting front $(\mathrm{cm})$, providing a good field estimate of runoff for large rainfall events (Fig. 5).

\section{Soil loss}

The scale of our study provides information on soil detached through raindrop impacts, the first stage in the process of soil erosion. Slope gradient and length were not considered. Although observed values were only a fraction of probable total soil loss, significant effects on sediment loss by vegetation cover were observed at the microsite-scale. The highest sediment loss by splash was in bare soil microsites (Fig. 4). Areas covered by Neobouteloua lophostachya, colonizer shortgrass of overgrazed sites, provided sufficient soil protection to reduce sediment detachment (Fig. 4). Singer et al. (1981) found that biomass cover reduced more transported than splash sediment, so vegetation effects are probably augmented at larger spatial scales. In shortgrass dominated sites, if plant cover were further degraded resulting in increased bare soil
The repeated-measure analysis of variance yielded a non-significant time $x$ treatment interaction, but microsite differences increased over time (significant time- $\mathrm{x}$ microsite- interaction, $\mathrm{P}<0.0001)$.

At the end of the 45-min period of simulated rainfall, runoff from tallgrass microsites was significantly lower than shortgrass and bare soil microsites (Fig. 4). Shortgrass and bare soil microsites had similar runoff, about $60 \%$. These estimates corresponded to $64-66 \mathrm{~mm}$ hour $^{-1}$ of observed runoff. Consequently, improvement of infiltration is expected, when management tools are used to promote the replacement of short low-productive pioneer grasses (e.g. Neobouteloua lophostachya [Gris.] Gould, Aristida adscencionis L, Sporobolus pyramidatus [Lam.] Hitchoock, and Michrochloa indica [L.F.] Beauv), by highly-productive tallgrasses (e.g. Aristida mendocina L, Trichloris crinita [Lag.] L.R. Parodi, Pappophorum caespitosum R.E.Fr.,

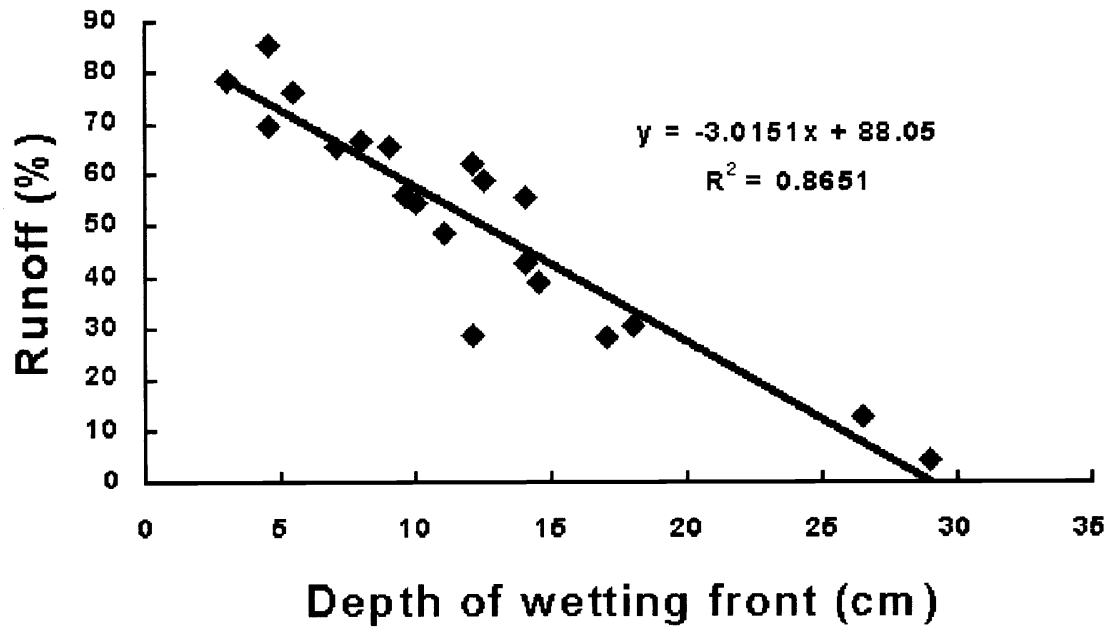

Fig. 5. Runoff related to depth of wetting front after simulation runs of $45 \mathrm{~min}$ at an average intensity of $110 \mathrm{~mm} \mathrm{hour}^{-1}(\mathrm{~N}=\mathbf{2 0})$. 


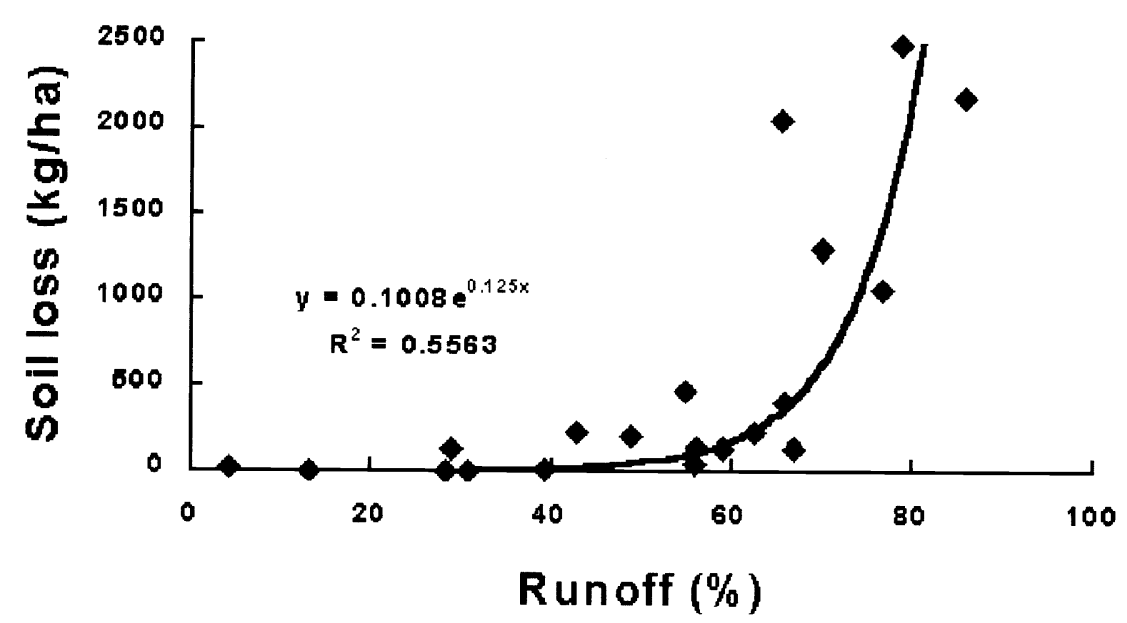

Fig. 6. Exponential relationship of sediment splash $\left(\mathrm{kg} \mathrm{ha}^{-1}\right)$ with runoff for simulation runs of $45 \mathrm{~min}$ at an average intensity of $110 \mathrm{~mm} \mathrm{hour}^{-1}(\mathrm{~N}=20)$.

cover, erosion would greatly accelerate. The relationship between runoff (\%) and sediment loss by splash $\left(\mathrm{kg} \mathrm{ha}^{-1}\right)$ demonstrated that beyond $60 \%$ (values of runoff for shortgrass cover-types), soil losses increased sharply (Fig. 6).

Tallgrass cover-types registered negligible soil loss, even after $45 \mathrm{~min}$ of rainfall at about $110 \mathrm{~mm} \mathrm{hour}^{-1}$. The present evaluation is relevant because most soil loss is often determined by high-intensity rainfall events under natural conditions (Castillo et al. 1997, Coronato and del Valle 1993, Rostagno et al. 1999). Consequences of high rainfall intensity events on aggregate breakdown and sediment transport have recently been determined for denuded and vegetated plots in a semiarid environment (Martínez-Mena et al. 1999). Although our comparative study did not evaluate sediment transported in rills or large concentrated flows, it shows the importance of vegetation cover to reduce the impact of rain splash. Besides, it is the first estimate of sediment losses for the semiarid Chaco.

Well-managed rangelands (adequate livestock rates and satisfactory rest periods) commonly posses stands with a high proportion of tallgrasses (Anderson et al. 1980). Increasing tallgrass cover may result in further increases of forage productivity via amelioration of hydrologic conditions of the rangeland site. We hypothesize that control of erosion should result in improvements of infiltration rates, thereby triggering a positive feedback mechanism resulting in higher primary productivity of the herbaceous vegetation layer.

\section{Management implications}

Caution should be taken to extrapolate results from microsites to the dynamics of landscape hydrology (Bergkamp 1998, Cammeraat and Imeson 1999). However, vegetation patch types are responsible for substantial transfer of water and sediments at small scales, of ecological significance in semiarid conditions (Reid et al. 1999). Cover-type of microsites appeared to determine runoff and soil losses in situ, more than overall disturbances per se in the shrublands studied in central Argentina. The evaluated roller-seeding treatment evaluated herein, reduced the proportion of microsites more exposed to erosion (bare soil and shortgrass covertypes). Reduction of runoff and soil loss are expected after using management techniques that result in vegetation dynamics promoting accumulation of litter, reduction of bare soil, and successional changes associated with the replacement of colonist shortgrasses by productive tallgrasses. This successional process must provide better condition ranges, resulting from more water infiltrated in the soil and increased forage production.

\section{Literature Cited}

Anderson, D.L., J. del Aguila, and A. Bernardón. 1970. Las formaciones vegetales en la provincia de San Luis. (In Spanish). Revista de Investigaciones Agropecuarias. INTA, Buenos Aires. Series 2:154-183.

Anderson, D.L., J.A. del Aguila, A. Marchi, J.C. Vera, E.L. Orionte, and A.E. Bernardón. 1980. Manejo Racional de un Campo en la Región Arida de Los Llanos de
La Rioja. (In Spanish). Instituto Nacional de Tecnología Agropecuaria, Buenos Aires, 90 pp.

Báez, J.R. 1946. Dos aspectos de la vegetación del norte de San Luis. II. Con mención sobre forrajeras y malezas. (In Spanish). Revista Argentina de Agronomía 13:69-95.

Basher, L.R. and I.H. Lynn. 1996. Soil changes associated with cessation of sheep grazing in the Canterbury High Country, New Zealand. New Zealand J. Ecol. 20:179-189.

Bergkamp, G. 1998. A hierarchical view of the interactions of runoff and infiltration with vegetation and microtopography in semiarid shrublands. Catena 33:201-220.

Black, C.A. 1965. Methods of Soil Analysis. Amer. Soc. of Agron. Series No. 9, Madison, Wis.

Blackburn, W.H., F.B. Pierson, C.L. Hanson, T.L. Thurow, and A.L. Hanson. 1992. The spatial and temporal influence of vegetation on surface soil factors in semiarid rangelands. Trans. ASAE 35:479-486.

Braunack, M.V. and J. Walker. 1985. Recovery of some surface soil properties of ecological interest after sheep grazing in a semi-arid woodland. Aust. J. Ecol. 10:451-460.

Cabido, M., C. González, A. Acosta, and S. Díaz. 1993. Vegetation changes along a precipitation gradient in Central Argentina. Vegetatio 109:5-14.

Cabido, M., A. Manzur, L. Carranza, and C. González Albarracín. 1994. La vegetación y el medio físico del Chaco Arido en la provincia de Córdoba, Argentina Central. (In Spanish). Phytocoenologia 24:423-460.

Cabrera, A.L. 1971. Fitogeografía de la República Argentina. (In Spanish). Boletín de la Sociedad Argentina de Botánica 14:1-42.

Cammeraat, L.H. and A.C. Imeson. 1999. The evolution and significance of soil-vegetation patterns following land abandonment and fire in Spain. Catena 37:107-127.

Castillo, V.M., M. Martínez-Mena, and J. Albadalejo. 1997. Runoff and soil loss response to vegetation removal in a semiarid envieronment. Soil Sci. Soc. Amer. J. 61:1116-1121.

Cerdá, A. 1999. Parent material and vegetation affect soil erosion in eastern Spain. Soil Sci. Soc. Amer. J. 63: 362-368.

Chanasyk, D.S. and M.A. Naeth. 1995. Grazing impacts on bulk density and soil strength in the foothills fescue grasslands of Alberta, Canada. Can. J. Soil Sci. 75:551-557.

Coronato, F.R. and H.F. del Valle. 1993. Methodological comparison in the estimate of fluvial erosion in an arid closed basin of northeastern Patagonia. J. Arid Environ. 24:231-239.

Daget, P. and J. Poissonet. 1971. Une méthode d'analyse phytologique des prairies (In French). Annales Agronomiques 22:5-41.

Eckert, R.E., F.F. Peterson, and J.T. Belton. 1986. Relation between ecological-range condition and proportion of soil-surface types. J. Range Manage. 39:409-414. 
Frasier, G.W., M. Weltz, and L. Weltz. 1998. Rainfall simulator runoff hydrograph analysis. J. Range Manage. 51:531-535.

Gardener, C.J. and J.G. McIvor. 1986. Characteristics associated with the colonizing ability of introduced pasture species in the semi-arid tropics, p. 456-457. In: P.J. Joss, P.W. Lynch, and O.B. Williams (eds.) Rangelands: a resource under siege. Aust. Acad. Sci., Canberra, Aust.

Hacker, J.B. 1989. The potential for buffel grass renewal from seed in 16-year-old buffel grass-siratro pastures in south-east Queensland. J. Appl. Ecol. 26:213-222.

Irurtia, C.B. and R. Mon. 1994. Microsimulador de lluvia para determinar infiltración a campo (In Spanish). INTA. Instituto de Suelos. Publicación No. 176. Castelar, Buenos Aires.

Knight, R.W., W.H. Blackburn, and L.B. Merril. 1984. Characteristics of Oak Mottes, Edwards Plateau, Texas. J. Range Manage.37:534-537.

Mares, M.A., J. Morello, and G. Goldstein. 1985. The Monte desert and other subtropical semi-arid biomes of Argentina, with comments on their relation to North American arid areas, p. 203-237. In: M. Evenari, I. Noy-Meir, and D.W. Goodall (eds.) Ecosystems of the World, 12A: Hot Deserts and Arid Shrublands, A. Elsevier, Oxford.

Martínez-Mena, M., J. Alvarez Rogel, J. Albadalejo, and V.M. Castillo. 1999. Influence of vegetal cover on sediment particle size distribution in natural rainfall conditions in a semiarid environment. Catena 38:175-190.

McCalla II, G.R., W.H. Blackburn, and L.B. Merril. 1984. Effects of livestock grazing on sediment production, Edwards Plateau of Texas. J. Range Manage. 37:291-294.
Morello, J. 1958. La provincia Fitogeográfica del Monte (In Spanish). Op. Lilloana 2:1-155

Naeth, M.A., R.L. Rothwell, D.S. Chanasyk, and A.W. Bailey. 1990. Grazing impacts on infiltration in mixed prairie and fescue grassland ecosystems of Alberta. Can. J. Soil Sci. 70:593-605.

Namur, P. 1985. Buffel Grass: generalidades, implantación y manejo. (In Spanish) Instituto Nacional de Tecnología Agropecuaria. EEA La Rioja, Chamical, La Rioja.

Passera, C.B., O. Borsetto, and L.I. Allegretti. 1996. Short-term effects of shrub control on two different plant communities in Argentina. J. Arid Environ. 34:415-420.

Passera, C.B., O. Borsetto, R.J. Candia, and C.R. Stasi. 1983. Método del "Point Quadrat Modificado" (In Spanish), p. 135-152. In: R. Candia and R. Braun (eds.) Taller sobre arbustos forrajeros en zonas áridas y semiáridas. Argentina.

Passera, C.B., O. Borsetto, R.J. Candia, and C.R. Stasi. 1992. Shrub control and seeding influences on grazing capacity in Argentina. J. Range Manage. 45:480-482.

Peña Zubiate, C.A., D.L. Anderson, M.A. Demmi, J.L. Saenz, and A. d'Hiriart. 1998. Carta de Suelos y Vegetación de la Provincia de San Luis (In Spanish). Instituto Nacional de Tecnología Agropecuaria, EEA San Luis, Villa Mercedes.

Reid, K.D., B.P. Wilcox, D.D. Breshears, and L. MacDonald. 1999. Runoff and erosion in a Piñon-Juniper woodland: influence of vegetation patches. Soil Sci. Soc. Amer. J. 63:1869-1879.

Rostagno, C., F. Coronato, H. del Valle, and D. Puebla. 1999. Runoff and erosion in five land units of a closed basin of norhteastern Patagonia. Arid Soil Res. Rehab. 13:281-292.
Singer, M.J., Y. Matsuda, and J. Blackard. 1981. Effect of mulch rate on soil loss by raindrop splash. Soil Sci. Soc. Amer. J. 45: 107-110.

Skousen, J.G. and C.A Call. 1987. Grass and forb species for revegetation of mixed soillignite overburden in East Central Texas. J. Soil Water Conserv. 42:438-442.

Snedecor, G.W. and W.G. Cochram. 1980. Statistical Methods. The Iowa State University Press, Ames, Iowa.

Soil Survey Staff. 1999. Soil Taxonomy. A basic system of soil classification for making and interpreting soil surveys. USDA-NRCS, Agr. Handb. No 436, $2^{\text {nd }}$ ed. U.S. Gov. Print. Office, Washington DC.

Thurow, T.L., W.H. Blackburn, and C.A. Taylor, Jr. 1986. Hydrologic characteristics of vegetation types as affected by livestock grazing systems, Edwards Plateau, Texas. J. Range Manage. 39:505-509.

Valentin, C., J.M. d'Herbès, and J. Poesen. 1999. Soil and water components of banded vegetation patterns. Catena 37:1-24.

Weixelman, D.A., D.C. Zamudio, K.A. Zamudio, and R.J. Tausch. 1997 Classifying ecological types and evaluating site degradation. J. Range Manage. 50:315-321.

Wood, M.K. and W.H. Blackburn. 1981 Grazing systems: their influence on infiltration rates in the Rolling Plains of Texas. J. Range Manage. 34:331-335.

Wood, M.K. and W.H. Blackburn. 1984. Vegetation and soil responses to cattle grazing systems in the Texas Rolling Plains. $\mathrm{J}$. Range Manage. 37:303-308. 